\title{
Medijske navike, povjerenje publike i lažne vijesti u doba koronavirusa
}

Izvorni znanstveni rad, DOI 10.22522/cmr20210162, primljeno 10. svibnja 2021.

UDK : $\quad 316.774: 392$

070.18

\section{Petra Begović}

Fakultet hrvatskih studija Sveučilišta u Zagrebu, Zagreb, Hrvatska.

E-adresa: petra.pbegovic@gmail.com

\section{Prof. dr. sc. Danijel Labaš (kontakt osoba)}

Fakultet hrvatskih studija Sveučilišta u Zagrebu, Zagreb, Hrvatska.

E-adresa: dlabas@hrstud.hr

$\ldots \ldots \ldots \ldots$

\section{Sažetak}

U ovom su radu analizirane navike korištenja medija, posebno digitalnih, vjerodostojnost njihovog sadržaja u očima publike i mišljenja o lažnim vijestima za vrijeme kriznoga razdoblja, koje je poznato i kao „doba pandemije koronavirusa“, dok je Svjetska zdravstvena organizacija upozorila i na činjenicu da je istodobno riječ bila i o infodemiji. Upravo je tim terminom potvrđena važnost uloge medija, koji su mogli pridonijeti smirivanju krize ili su mogli prenositi dezinformacije, lažne vijesti i vijesti vezane uz teoriju zavjere i to upravo u doba kada su publici bili najpotrebniji. Ovo istraživanje, čiji je cilj bio ispitati ulogu medija kao važnog izvora informacija u doba pandemije koronavirusa, provedeno je metodom ankete putem interneta od 27. travnja do 15. svibnja 2020. godine. Rezultati istraživanja pokazali su da su mediji važan izvor informacija u koje ispitanici imaju povjerenja, a informacije su im pomogle u samom razumijevanju krize i usmjeravanju prema odgovarajućem ponašanju u kriznoj situaciji.

Ključne riječi: mediji, medijske navike, vjerodostojnost, lažne vijesti, koronavirus, komuniciranje u krizi 


\section{Uvod}

Činjenica je da mediji danas imaju važnu ulogu u svim društvima, kako u redovitim tako još i više u neredovitim, to jest kriznim razdobljima kakvo je zbog pandemije koronavirusa zahvatilo cijeli svijet na početku 2020. godine. Mediji kao prijenosnici informacija o aktualnim društvenim, kulturnim, političkim, gospodarskim i drugim događajima i pojavama - kao što je bila pojava novog nepoznatog virusa - imaju brojne funkcije koje Vlasta Kučiš, Nika Đuho i Ivan Balabanić (2019, str. 42) dijele u nekoliko kategorija: „(1) informiranje građana o najvažnijim pitanjima zajednice; (2) artikulacija stvarnosti ili oblikovanje medijske predodžbe o nekom događaju, fenomenu, pojavi i njegovim glavnim akterima; (3) uspostavljanje prioritetnih društvenih tema (agenda setting); (4) kritika i kontrola vlasti, političkih stranaka, političara i ostalih vršitelja javnih dužnosti; (5) zabava; (6) obrazovanje; (7) socijalizacija, te (8) integracija ili spajanje različitih ljudi, kultura i ideja“.

Danas je jedna od neugodnih posljedica razvoja događaja i ta da se previše toga događa istodobno, a netočne se informacije - zbog razvoja novih tehnologija - brzo pojavljuju i množe u svim medijima, a posebno na internetu i društvenim mrežama (Propaganda. mediaeducationlab.com, 2020). Ono što je prema Ani Tkalac Verčič (2015) također vrlo važno spomenuti činjenica je da i blogeri i mediji, kao i novinari i javnost, to jest publika prate ne samo vijesti, nego i glasine, koje onda komentiraju političari i javne osobe, pokušavajući objasniti što se događa. Mediji su oni koji traže i očekuju odgovore kako bi ih mogli prenijeti svojoj publici i svima zainteresiranima za ono što se događa u krizama, bez obzira jesu li one - kako piše Božidar Novak - prirodne, tehnološke, poslovne i ekonomske, uzrokovane sukobom, zlonamjernošću, vrijednostima upravljanja, obmanom ili uzrokovane lošim poslovanjem uprave (prema Tomić, Milas, 2007, str. 141). Posebnu ulogu u doba krize imaju mediji na koje se u takvim razdobljima publika oslanja još i više nego li $u$ „redovito" vrijeme. S normativnoga pak gledišta i sami su mediji danas u krizi, naglašava Marko Ivanišin (2011), ali oni u doba krize jednako tako imaju ulogu voditi publiku u moralnim i etičkim pitanjima, dužni su objektivno i pošteno izvještavati, izbjegavati manipulacije i prenošenje neprovjerenih i lažnih informacija, to jest dezinformacija koje danas najčešće nazivamo „fake news”. 


\section{Percepcija krize î potreba za informacijama}

Novi koronavirus ${ }^{1}$, koji se pojavio 2019. nazvan je SARS-CoV-2, prouzročio je svjetsku krizu, a Božidar Novak smatra da način ponašanja ljudi određuje veličinu krize i kako ju uopće shvaćaju. Novak (2000, str. 100) piše: „Kad bi, naime, svi ljudi racionalno razmišljali, krize tada uopće ne bi bile tako značajne. U većini slučajeva prava kriza nije ono što se uistinu dogodilo, već ono što ljudi misle da se dogodilo“. Tako se krajem 2019. i početkom 2020. u Hrvatskoj tek tu i tamo razgovaralo o virusu koji se širi u kineskom gradu Wuhanu. Jačanjem virusa i prijenosom među ljudima, Europa je postala novo žarište, posebno Italija i Španjolska, kasnije i Francuska. Čim nam je virus bio blizu i kada je 25. veljače 2020. potvrđen prvi slučaj zaraze u Hrvatskoj, hrvatski građani su osjećali strah. Otvaranje trijažnih centara, karantena, formiranje Nacionalnog stožera, kao i uvođenje protuepidemijskih mjera utjecalo je na percepciju ljudi koji su se osjećali ugroženo i bojali se virusa, nevidljivog neprijatelja koji nas može zaraziti. U takvim okolnostima širenja nevidljivog virusa, ljudi su pojačano doživljavali svijet oko sebe, kao i sve potencijalne opasnosti. Jačali su strah, nemir, a stres i paniku je kod nekih pojedinaca izazvalo i širenje lažnih vijesti o bolesti, njezinom nastanku, širenju te posljedicama za ljude i naš život. No, nakon najjačeg stresnog učinka i krizne adaptacije, a kako objašnjavaju Kristina Wied, Judith Pies, Thilo Büsching (2020), uslijedilo je smirivanje krize kada se život vraća u normalnu kolotečinu, zahvaljujući i pravodobnim i točnim informacijama koje se danas brzo šire zahvaljujući razvoju medija, a posebno internetu, to jest digitalnim medijima.

\subsection{Digitalni mediji i medijske navike publike}

Kao što je činjenica da su mediji važni društvu, Mario Plenković (2015, str. 116) utvrđuje „da današnje doba sve više određuje digitalizirana komunikacija, informacijski i komunikacijski procesi, stapanje različitih medija, korištenje novih medija, mobilne tehnologije, društvene mreže te nezaustavljiva mreža građana interneta“.

U suvremenom društvu posebno su vrijedna kvantitativna istraživanja o medijskim navikama, a jedno takvo je Ipsos Content proveo za 24 sata u siječnju 2019. godine. U istraživanju je sudjelovalo 1023 ispitanika u dobi od 18 do 60 godina. Rezultati su pokazali da je internet najkorišteniji medij prema učestalosti korištenja, mjestima i dobu dana u kojemu 
se prati. Vodeći je kao glavni izvor informacija koje nije moguće drugdje pronaći, a još je u 2017. prestigao televiziju te se nametnuo kao najpouzdaniji izvor kojem korisnici najviše vjeruju. Uz internet, televizija ima najveći doseg, a korisnici je najviše prate u večernjim satima (Showcase.24sata.hr, 2020). Prema istom istraživanju, najvažniji medijski sadržaji su vijesti iz zemlje i lokalne vijesti, a u kontekstu našega rada važno je istaknuti da slijede sadržaji o zdravlju, sport, glazba, znanost i tehnologija (27-29\% ispitanika). Ispitanici prate medije zbog potrebe za informiranjem (70,2\%), zbog dnevne rutine $(62,3 \%)$ te zbog razumijevanja događaja koji utječu na njihov život $(58,8 \%)$. Uz medije se zabavlja i opušta 49,5\% ispitanika, a krati vrijeme njih 45,5\%. Za izvor tema s prijateljima i kolegama medije koristi 30,2\% ispitanika. YouTube je prva mreža ili komunikacijski kanal po broju korisnika $(92,7 \%)$ ali prema vremenu koje korisnici dnevno provedu na mreži prvo mjesto zauzima Facebook (84,7\% korisnika).

\subsection{Mediji u doba koronavirusa}

Pandemiju koronavirusa obilježila je borba točnih, jasnih i „čistih“ informacija protiv dezinformacija, istina protiv laži, pouzdanih protiv nepouzdanih informacija. Lažnim vijestima smatramo nepostojeće ili iskrivljene činjenice koje zavaravaju publiku. Rezultati istraživanja Eurobarometra u veljači 2018. na više od 25 tisuća ispitanika pokazali su da čak $85 \%$ građana Europske unije prepoznaje lažne vijesti kao problem u njihovim državama. U Hrvatskoj se kao i u Portugalu u cijeloj EU najviše vjeruje vijestima i informacijama koje dobijemo putem društvenih mreža i ostalih komunikacijskih alata za dopisivanje (Edukacije.hr, 2020).

U Münchenu je sredinom veljače 2020. Svjetska zdravstvena organizacija sudjelovala na Konferenciji o sigurnosti kada je generalni direktor Tadros Adhanom Ghebreyesus istaknuo: „Lažne vijesti se šire brže i lakše nego virus - i isto toliko su opasne“ (DW.com, 2020). Upravo su zato razdoblje koronavirusa nazvali infodemijom zbog prevelike količine informacija koje su bile lažne i neutemeljene. Prva lažna informacija o koronavirusu iz ruskih izvora objavljena je 22. siječnja, a registrirala ju je služba EuvsDisinfo. Prema njoj, virus su kreirali ljudi i on je oružje koje je napravio NATO. Arapska služba Sputnik proširila je lažnu vijest o kreiranju koronavirusa u laboratoriju u SAD-u. Mediji bliski ruskom Kremlju širili su oprečne teorije: pandemija je prijevara, raspada se Šengenski sustav i NATO ili dolazi do kolapsa baltičkih država. Kineski diplomat je sredinom ožujka 2020. plasirao vijest da se koronavirus pojavio u jesen 2019. u 
SAD-u. Taj tweet kineskog diplomata proširilo je nekoliko kineskih veleposlanstava pa je on na kraju imao 12.000 retweetova i više od 20.000 lajkova. U SAD-u je bila aktualna kampanja u kojoj žele istaknuti da je koronavirus zapravo „kineski virus“ ili preciznije „wuhanski virus“. Isticali su da je virus nastao u Kini te da je ona prva znala za posljedice virusa i da je svjesno širila lažne informacije o izvoru pandemije. Još su u veljači u SAD-u plasirali informaciju da je izvor pandemije biološki laboratorij u Wuhanu (DW.com, 2020). Neprijeporna je činjenica da su društveni mediji poput Twittera, Facebooka i Instagrama, premda nisu mediji u pravome smislu te riječi, što potvrđuje i Thomas Zeilinger (2020), postali primarni izvori informacija u današnje doba. Tkalac Verčič (2015, str. 435) dodaje da je „Twitter idealan oblik komunikacije u kriznim situacijama ili kad je potrebno hitno objaviti određene vijesti“.

Unatoč lažnim vijestima koje su se javljale na društvenim mrežama, Kristine de Vlack istaknula je da su mediji osnovali platforme za širenje javnozdravstvenih poruka, npr. Facebook i Google uveli su informativne centre za koronavirus ili YouTube koji je prenosio podatke zdravstvenih tijela u nekim zemljama. Odgovornost medija bila je velika, a svi akteri u komunikacijskom procesu - od pošiljatelja do primatelja, od medija do publike - imali su i imaju svoju ulogu u sprječavanju širenja glasina i lažnih vijesti putem svojih računa na društvenim medijima (Hec.edu, 2020).

Tijekom ožujka i travnja 2020. Reutersov Institut i Sveučilište u Oxfordu proveli su anketno istraživanje u šest zemalja (Argentina, Njemačka, Južna Koreja, Španjolska, Ujedinjeno Kraljevstvo i Sjedinjene Američke Države). Korištenje vijesti povećano je u svih šest zemalja i većina ljudi u većini zemalja za vijesti i informacije okreće se društvenim medijima, tražilicama, video web sjedištima i aplikacijama za razmjenu poruka o koronavirusu. U Argentini, Južnoj Koreji, Španjolskoj i SAD-u mladi više vjeruju društvenim mrežama, dok u Njemačkoj, Velikoj Britaniji i SAD-u više vjeruju društvenim aplikacijama i komunikacijskim kanalima za razmjenu poruka. Visok je postotak ljudi (neovisno o dobi, obrazovnoj razini, političkoj ideologiji) koji vjeruju znanstvenicima, liječnicima i drugim zdravstvenim stručnjacima kao izvorima informacija o koronavirusu. Tri četvrtine ispitanika vjeruje nacionalnim ili međunarodnim organizacijama za javno zdravstvo, većina ih opisuje kao „relativno pouzdane“, a u svim zemljama, osim Španjolske i SAD-a, većina vjeruje i svojim nacionalnim vladama. Manjina kaže da je naišla na puno lažnih ili zbunjujućih vijesti o koronavirusu. Kao širitelji lažnih informacija prepoznati su ljudi koje ispitanici ne poznaju, dok su prema mišljenju 
ispitanika u drugim zemljama pojedini političari ti koji šire dezinformacije (Južna Koreja, Španjolska, SAD). Najviše lažnih vijesti pronađeno je na društvenim mrežama i aplikacijama za razmjenu poruka. Takva praksa sa širenjem lažnih vijesti pridonijela je da ispitanici vijesti o koronavirusu smatraju preuveličanima, no optimizam u ovom istraživanju pokazuju rezultati prema kojima većina ispitanika potvrđuje da su im mediji pomogli da razumiju krizu i objasne što mogu učiniti (Reutersinstitute.politics.ox.ac.uk, 2020).

\section{Metodologija, cilj ì svrha rada}

Istraživanje, čiji je cilj bio ispitati ulogu medija kao važnog izvora informacija u doba pandemije koronavirusa (PANCOVID-19), provedeno je metodom ankete. Ksenija Dumičić i Berislav Žmuk (2009, str. 117.) anketu definiraju kao „postupak pomoću kojeg se prikupljaju i analiziraju podaci prikupljeni od ljudi kako bi se saznali detalji o njihovu ponašanju ili o njihovim stavovima, mišljenjima, namjerama, preferencijama ili interesima. Ona se primjenjuje na uzorku pomoću kojeg se zatim, ako se radi o znanstvenoj primjeni, zaključci mogu proširiti i na širi društveni kontekst iz kojeg je uzorak izabran te se upotrijebiti za predviđanje budućeg ponašanja. Svrha je ankete doći do procjena, odnosno numeričkih opisa neke karakteristike istraživane populacije“. Dumičić i Žmuk (2009) ističu da se anketa koristi u brojnim znanostima, a osobito u sociologiji, psihologiji, komunikologiji i novinarstvu. Za ovaj je rad anketa formirana i provedena putem interneta (Google obrazac) od 27. travnja do 15. svibnja 2020. godine. U anketi je sudjelovalo 585 ispitanika u dobi od 18 do 65 godina s područja cijele Hrvatske. Anonimni anketni upitnik sadržavao je 37 pitanja, na koja su ispitanici mogli dati jedan ili više odgovora.

Glavna hipoteza istraživanja bila je: Mediji su važan izvor informacija u koje korisnici imaju povjerenja. Svrha istraživanja je ispitati medijske navike hrvatskih građana u doba PANCOVID-19, koje medije najčešće koriste i u koje svrhe, koje sadržaje najviše prate putem medija, jesu li se promijenile njihove navike u odnosu na razdoblje prije PANCOVID-19, imaju li po-

vjerenja u medije, kako vrednuju djelovanje novinara i jesu li mediji pridonijeli razumijevanju opasnosti od zaraze COVIDom-19. 


\subsection{Rezultati istraživanja i rasprava}

U anketnom je istraživanju sudjelovalo 585 ispitanika, odnosno 77,1\% ispitanica i 22,9\% ispitanika (Tablica 1). U najvećem broju pripadaju dobnoj skupini od 31 do 45 godina (39,8\%). Najveći broj ispitanika živi na području Grada Zagreba (42,4\%) i Zagrebačke županije (22,9\%), dok je najmanje ispitanika s područja Koprivničko-križevačke, Karlovačke i Međimurske županije (0,5\%).

Tablica 1. Spol, dob i područje stanovanja $(\mathrm{N}=585)$

\begin{tabular}{|l|l|}
\hline Spol ispitanika (N=585) & \\
\hline Ž & $77,1 \%$ \\
\hline M & $22,9 \%$ \\
\hline Dob ispitanika (N=585) & \\
\hline $31-45$ & $39,8 \%$ \\
\hline $18-30$ & $35,6 \%$ \\
\hline $46-55$ & $16,4 \%$ \\
\hline $56-65$ & $8,2 \%$ \\
\hline Područje stanovanja (N=585) & \\
\hline Grad Zagreb & $42,4 \%$ \\
\hline Zagrebačka & $22,9 \%$ \\
\hline Splitsko-dalmatinska & $5,8 \%$ \\
\hline Osječko-baranjska & \\
\hline Vukovarsko-srijemska & $3,2 \%$ \\
\hline Primorsko-goranska & $2,6 \%$ \\
\hline Dubrovačko-neretvanska & $2,2 \%$ \\
\hline Sisačko-moslavačka & $2,2 \%$ \\
\hline Krapinsko-zagorska & $2,2 \%$ \\
\hline Zadarska & $1,9 \%$ \\
\hline Požeško-slavonska & $1,7 \%$ \\
\hline Istarska & $1,4 \%$ \\
\hline Bjelovarsko-bilogorska & $1,4 \%$ \\
\hline Varaždinska & $1,4 \%$ \\
\hline Brodsko-posavska & $0,9 \%$ \\
\hline Šibensko-kninska & $0,9 \%$ \\
\hline Koprivničko-križevačka & $0,5 \%$ \\
\hline Karlovačka & $0,5 \%$ \\
\hline Međimurska & $0,5 \%$ \\
\hline & \\
\hline & \\
\hline
\end{tabular}

Kako bismo mogli utvrditi njihove medijske navike, prvo smo naše ispitanike pitali koliko su im mediji važni u svakodnevnome životu i u koje ih svrhe koriste. Iz Tablice 2 vidljivo 
je da 49,6\% ispitanika ističe da su im mediji važni u svakodnevnom životu ili njih 12,5\% kojima su mediji u potpunosti važni.

Tablica 2. Važnost medija u svakodnevnom životu (N=585)

\begin{tabular}{|l|l|}
\hline Uopće mi nisu važni & $2,4 \%$ \\
\hline Nisu mi važni & $4,1 \%$ \\
\hline Niti su mi nevažni niti važni & $31,5 \%$ \\
\hline Važni su mi & $49,6 \%$ \\
\hline U potpunosti su mi važni & $12,5 \%$ \\
\hline
\end{tabular}

Tablica 3 pokazuje da više od polovice ispitanika (53,8\%) medije koristi za sve navedene svrhe (informiranje, odgoj i obrazovanje, zabava). Pod kategorijom Ostalo ispitanici su rekli da medije koriste za posao, za „ubijanje vremena“, zbog navike ili u razne svrhe, dok neki ignoriraju medije.

Tablica 3. Svrha korištenja medija $(\mathrm{N}=585)$

\begin{tabular}{|l|l|}
\hline Za informiranje & $33,2 \%$ \\
\hline Za zabavu & $8,9 \%$ \\
\hline Za odgoj i obrazovanje & $2,2 \%$ \\
\hline Za sve navedeno & $53,8 \%$ \\
\hline Ostalo & $0,2 \%$ \\
\hline
\end{tabular}

Prema Tablici 4, vidljivo je da je 58,5\% ispitanika u doba koronavirusa medije najviše koristilo za informiranje, što je ukazalo na značajniji porast korištenja medija u odnosu na razdoblje prije pandemije. U kategoriji Ostalo ispitanici su navodili da koriste medije zbog navike čitanja, zbog posla, praćenja trendova u svijetu, no i provjere medijske moći da manipuliraju svojim korisnicima.

Tablica 4. Svrha korištenja medija za vrijeme PANCOVID-19 (N=585)

\begin{tabular}{|l|l|}
\hline Za informiranje & $58,5 \%$ \\
\hline Za sve navedeno & $33 \%$ \\
\hline Za zabavu & $5,5 \%$ \\
\hline Za odgoj i obrazovanje & $1,7 \%$ \\
\hline Ostalo & $0,2 \%$ \\
\hline
\end{tabular}


Kako je vidljivo iz Tablice 5, ispitanici su mogli ponuditi višestruke odgovore pa zaključujemo da se ispitanici informiraju iz različitih vrsta medija na nacionalnoj i lokalnoj razini. Prvi izvor informacija za $72,6 \%$ ispitanika su nacionalne TV postaje, a slijede nacionalni $(65,8 \%)$ i lokalni internetski portali (29,2\%). Pod kategorijom Ostalo u ovome su pitanju ispitanici navodili da se informiraju putem službene stranice Vlade RH, portala koronavirus.hr ${ }^{1}$, inozemnih portala, društvenih mreža, portala Svjetske zdravstvene organizacije, ali i putem osobnog kontakta i komunikacije s obitelji, prijateljima, te blagajnicom u trgovini.

Tablica 5. Najčešće korišteni medij za informiranje o novostima vezanima uz COVID-19 (N=585)

\begin{tabular}{|l|l|}
\hline Nacionalne TV postaje & $72,6 \%$ \\
\hline Nacionalni internetski portali & $65,8 \%$ \\
\hline Lokalni internetski portali & $29,2 \%$ \\
\hline Lokalne TV postaje & $13,2 \%$ \\
\hline Nacionalne radijske postaje & $12,1 \%$ \\
\hline Nacionalne dnevne novine & $11,5 \%$ \\
\hline Lokalne radijske postaje & $10,9 \%$ \\
\hline Lokalne novine & $3,9 \%$ \\
\hline Ostalo & $0,2 \%$ \\
\hline
\end{tabular}

Internet je na prvome mjestu po korištenju za vrijeme PANCOVID-19, a ispitanici su ga najviše koristili u informativne svrhe - njih čak 88,5\% (Tablica 6). Slijedi televizija koju je pratilo visokih $80,9 \%$ ispitanika. Vidljivo je isto tako da ispitanici internet najviše koriste i u odgojno-obrazovne (87,9\%), ali i u zabavne svrhe (79,7\%). Televiziju su ispitanici u odgojno-obrazovne koristili u znatno nižem postotku (46,2\%), društvene mreže su na trećem mjestu s $28,9 \%$, dok određeni broj ispitanika ne koristi medije u odgojno-obrazovne svrhe. Ostali rezultati ispitivanja učestalosti korištenja medija u zabavne svrhe pokazali su da su televizija i društvene mreže zamijenile mjesta te je vidljiv značajniji porast korištenja društvenih mreža za zabavu (72,6\%), dok je televizija na trećem mjestu s 58,8\%.

1 Www.koronavirus.hr je službena stranica Vlade RH za pravodobne i točne informacije o koronavirusu. Dosadašnja istraživanja (Utz i suradnici, Coombs i Holladay, Kulkarni) bavila su se učincima različitih online platformi te učinkovitošću medija u kriznom komuniciranju. Istraživanja su pokazala da službene internetske stranice, poput www.koronavirus. $\underline{\mathrm{hr}}$, funkcioniraju kao svojevrsna oglasna ploča i pružaju autorizirane informacije jedne strane te time zadržavaju svoju informativnu vrijednost (Kanajet, Jakopović, 2019: 64). 
Tablica 6. Korištenje medija u informativne, odgojno-obrazovne i zabavne svrhe za vrijeme PANCOVID-19

\begin{tabular}{|l|l|l|l|l|l|}
\hline Medij & $\begin{array}{l}\text { Informativna } \\
\text { svrha }\end{array}$ & Medij & $\begin{array}{l}\text { Odgojno-obra- } \\
\text { zovna svrha }\end{array}$ & Medij & Zabavna svrha \\
\hline Internet & $88,5 \%$ & Internet & $87,9 \%$ & Internet & $79,7 \%$ \\
\hline Televizija & $80,9 \%$ & Televizija & $46,2 \%$ & Društvene mreže & $72,6 \%$ \\
\hline Društvene mreže & $52 \%$ & Društvene mreže & $28,9 \%$ & Televizija & $58,8 \%$ \\
\hline Radio & $26,2 \%$ & Radio & $9,7 \%$ & Radio & $23,9 \%$ \\
\hline Ostalo & $0,2 \%$ & Ne koristim & $0,7 \%$ & Ostalo & $0,2 \%$ \\
\hline & & Ostalo & $0,2 \%$ & & \\
\hline
\end{tabular}

Zanimljiv je i podatak iz Tablice 7 prema kojemu je kriza izazvana koronavirusom uzrokovala učestalije korištenje medija kod 50,6\% ispitanika, jednako ih je koristilo njih 41,9\%, dok je znatno manji bio postotak onih koji su medije koristili manje nego prije $(3,8 \%)$ ili onih koji to nisu mogli odrediti (3,7\%), što samo potvrđuje naše početne tvrdnje da su mediji važni čimbenici u društvu, te osobito važni u kriznim vremenima.

Tablica 7. Učestalost korištenja medija za vrijeme PANCOVID-19 (N=585)

\begin{tabular}{|l|l|}
\hline Više nego prije & $50,6 \%$ \\
\hline Jednako & $41,9 \%$ \\
\hline Manje nego prije & $3,8 \%$ \\
\hline Ne mogu odrediti & $3,7 \%$ \\
\hline
\end{tabular}

Iz Tablice 8 vidljivo je da su najčešći razlozi za učestalije korištenje medija bili potreba za informacijama (57\%), ali i višak vremena (40,1\%).

Tablica 8. Razlozi učestalijeg korištenje medija ( $\mathrm{N}=509)$

\begin{tabular}{|l|l|}
\hline Potreba za informacijama & $57 \%$ \\
\hline Višak vremena & $40,1 \%$ \\
\hline Znatiželja & $36,9 \%$ \\
\hline Dosada & $25,1 \%$ \\
\hline Izvor inspiracije & $10,8 \%$ \\
\hline Nije se povećalo & $5 \%$ \\
\hline Nastava na daljinu, obrazovanje, školovanje & $2 \%$ \\
\hline Posao & $1 \%$ \\
\hline Ostalo & $0,2 \%$ \\
\hline
\end{tabular}


Prema Tablici 9 HTV je bio najgledanija televizija s 35\% ispitanika, dok slijede RTL s 24,1\% i NOVA TV s $21,7 \%$. Pod kategorijom Ostalo (13,6\%) ispitanici su istaknuli da ne gledaju televiziju ili da ne posjeduju televizor, dok dio ispitanika podjednako prati sve televizije ili praćenje televizijskog programa ovisi o terminu i kanalu. Tako ispitanici prate DOMA TV, HBO, Laudato TV, RTL 2, RTL Crime, MTV TV, CINESTAR TV, VH1, RTL Kockica, a izdvojene su još N1 s 4,4\% i lokalne televizije koje prati 1,2\% ispitanika.

Tablica 9. Najgledanija televizija za vrijeme PANCOVID-19 (N=585)

\begin{tabular}{|l|l|}
\hline HTV & $35 \%$ \\
\hline RTL TV & $24,1 \%$ \\
\hline NOVA TV & $21,7 \%$ \\
\hline Ostalo & $13,6 \%$ \\
\hline N1 & $4,4 \%$ \\
\hline Lokalna televizija & $1,2 \%$ \\
\hline
\end{tabular}

Nacionalni stožer civilne zaštite za vrijeme krize služio je kao temeljni izvor informacija. Rezultati pokazuju da su ispitanici te konferencije najčešće pratili svakodnevno (27,5\%), često ih je pratilo njih $27,4 \%$, a povremeno $21,5 \%$.

Tablica 10. Učestalost praćenja konferencija Nacionalnog stožera civilne zaštite Republike Hrvatske $(\mathrm{N}=585)$

\begin{tabular}{|l|l|}
\hline Svakodnevno & $27,5 \%$ \\
\hline Često & $27,4 \%$ \\
\hline Povremeno & $21,5 \%$ \\
\hline Rijetko & $14,9 \%$ \\
\hline Nikada & $8,7 \%$ \\
\hline
\end{tabular}

Budući da je internet bio najkorišteniji medij, što je vidljivo iz naše Tablice 6, zanimljiva je Tablica 11 iz koje je vidljivo da su ispitanici najviše pratili portale dnevnih novina (67,5\%), no rado su praćeni i dnevno informativni portali koji nemaju tiskano izdanje. Njih prati $50,6 \%$ ispitanika, dok nešto manje prate portale televizija (26,7\%) i lokalne portale $(16,2 \%)$. Među portalima koje prate 460 ispitanika je izdvojilo Vecernji.hr, Jutarnji.hr, Indeks.hr, Net. hr, Tportal.hr, Telegram.hr, Dnevnik.hr, Narod.hr, hrt.hr, koronavirus.hr, dnevno.hr, slobodnadalmacija.hr, bitno.net, direktno.hr, radio.hrt.hr, te lokalne, regionalne i županijske portale s područja cijele Hrvatske (sisak.info, dulist.hr, dalmatinskiportal.hr, zagorje.com). 
Tablica 11. Najčitaniji portali za vrijeme PANCOVID-19 (N=585)

\begin{tabular}{|l|l|}
\hline Portali dnevnih novina & $67,5 \%$ \\
\hline $\begin{array}{l}\text { Dnevno informativni portali (nemaju tiskano } \\
\text { izdanje) }\end{array}$ & $50,6 \%$ \\
\hline Portali televizija & $26,7 \%$ \\
\hline Lokalni portali & $16,2 \%$ \\
\hline Radijski portali & $7,2 \%$ \\
\hline Ništa & $0,5 \%$ \\
\hline Ostalo & $0,2 \%$ \\
\hline
\end{tabular}

Rezultati iz Tablice 12 pokazuju da je Facebook najkorištenija društvena mreža ispitanika (85,6\%), a slijede WhatsApp (75,2,\%), YouTube (56,4\%), Instagram (51,5\%) i Viber (47,5\%). U nešto manjoj mjeri se koriste Skype (12,8\%), LinkedIN (11,8\%), Twitter (8,4\%) i Pinterest (7,9\%).

Tablica 12. Najposjećenije društvene mreže i komunikacijski kanali za vrijeme PANCOVID-19 (N=585)

\begin{tabular}{|l|l|}
\hline Facebook & $85,6 \%$ \\
\hline WhatsApp & $75,2 \%$ \\
\hline YouTube & $56,4 \%$ \\
\hline Instagram & $51,5 \%$ \\
\hline Viber & $47,5 \%$ \\
\hline Skype & $12,8 \%$ \\
\hline LinkedIN & $11,8 \%$ \\
\hline Twitter & $8,4 \%$ \\
\hline Pinterest & $7,9 \%$ \\
\hline Reddit & $3,9 \%$ \\
\hline Snapchat & $3,4 \%$ \\
\hline Tumblr & $0 \%$ \\
\hline
\end{tabular}

Svi mediji redovno su pratili krizu izazvanu koronavirusom, te otkrivali niz detalja i informacija o bolesti, njezinom tijeku i širenju, ali i načinu sprječavanja širenja bolesti. Ispitanike je najviše zanimao, kao što pokazuje Tablica 13 , broj zaraženih $(69,9 \%)$ o čemu smo bili informirani putem konferencija Nacionalnog stožera civilne zaštite Republike Hrvatske, a čije su informacije prenosili i ostali mediji. Slijedi gospodarska kriza (52\%), online nastava (42,2 \%), život tijekom PANCOVID-19 (39,8\%) kao i život nakon PANCOVID-19 (36,6\%). Ispitanici su pokazali interes i za temu o promjenama navika građana tijekom PANCOVID-19 (32,8\%), dok je pad turističke sezone kao tema zanimala 28,5\% ispitanika. Ispitanici su 
među ostalim naveli da su pretraživali duhovne sadržaje ili teme o vrtlarstvu, $5 \mathrm{G}$ mreži, o COVID-19 kao prevari, o mortalitetu i ispunjavanju smrtovnica, o koroni u Italiji itd.

Tablica 13. Najzanimljivije podteme o COVIDu-19 ( $\mathrm{N}=585)$

\begin{tabular}{|l|l|}
\hline Broj zaraženih & $69,9 \%$ \\
\hline Mjere, njihovo uvođenje i relaksacija & $61,9 \%$ \\
\hline Gospodarska kriza & $52 \%$ \\
\hline Online nastava & $42,2 \%$ \\
\hline Život tijekom PANCOVID-19 & $39,8 \%$ \\
\hline Život nakon PANCOVID-19 & $36,6 \%$ \\
\hline Promjene navika građana tijekom PANCOVID-19 & $32,8 \%$ \\
\hline Informacije o načinu testiranja i testovima & $32 \%$ \\
\hline Cjepivo protiv COVID-19 & $30,3 \%$ \\
\hline Pad turističke sezone & $28,5 \%$ \\
\hline Ostalo & $0,2 \%$ \\
\hline
\end{tabular}

Prema mišljenju ispitanika, mediji su uspješno proizvodili sadržaje za vrijeme pandemije koronavirusa (Tablica 14). Unatoč zatvaranju muzeja, knjižnica, odgojno-obrazovnih institucija, prestanku sportskih natjecanja ili koncerata i glazbenih nastupa, 35\% ispitanika nije primijetilo manjak sadržaja u medijima, ali su im ipak najviše nedostajali zabavni (33,5\%), sportski (30,1\%) i kulturni sadržaji (27,7\%), a najmanje mozaički sadržaji $(7,2 \%)$.

Tablica 14. Sadržaji koji su nedostajali publici $(\mathrm{N}=585)$

\begin{tabular}{|l|l|}
\hline Nisam primijetio/la manjak sadržaja & $35 \%$ \\
\hline Zabavni sadržaji & $33,5 \%$ \\
\hline Sportski sadržaji & $30,1 \%$ \\
\hline Kulturni sadržaji & $27,7 \%$ \\
\hline Mozaični sadržaji & $7,2 \%$ \\
\hline Ostalo & $0,2 \%$ \\
\hline
\end{tabular}

Kada je riječ o vrsti sadržaja koje su mediji prenosili online, vidljivo u Tablici 15, ispitanici su najviše pratili informativne sadržaje $(72,8 \%)$, a znatno manje svakodnevne sadržaje (34\%), odgojno-obrazovne (28,4\%), vjerske (27\%) te glazbene sadržaje (26\%). 
Tablica 15. Najpraćeniji sadržaji online tijekom PANCOVID-19 ( $\mathrm{N}=585)$

\begin{tabular}{|l|l|}
\hline Informativne sadržaje & $72,8 \%$ \\
\hline Svakodnevne sadržaje & $34 \%$ \\
\hline Odgojno-obrazovne sadržaje & $28,4 \%$ \\
\hline Vjerske sadržaje & $27 \%$ \\
\hline Glazbene sadržaje & $26 \%$ \\
\hline Gospodarske sadržaje & $17,1 \%$ \\
\hline Kulturne sadržaje & $16,6 \%$ \\
\hline Ništa & 0,3 \\
\hline Ostalo & 0,2 \\
\hline
\end{tabular}

Broj zaraženih, protuepidemijske mjere, način sprječavanja širenja bolesti, život tijekom bolesti, gospodarska kriza - samo su neke od podtema koje su zauzele medijski prostor, ali su u istom razdoblju ispitanici, prema Tablici 16, primijetili da je u medijima manje političkih tema (52\%), manje crne kronike (32,1\%) i senzacionalizma (29,9\%). Rezultati su pokazali da su ispitanici također primijetili da je manje istine, a više teorija zavjere (27,5\%). Teorije zavjere bile su vezane uz pripisivanje početka širenja bolesti iz Kine u ostatak svijeta, a kako se proširila Europom govorilo se da je bolest nastala laboratorijski, sve do druge krajnosti u kojoj se postavljalo pitanje: postoji li uopće bolest nazvana COVID-19? Ispitanici su jednako tako primijetili manje prikrivenog oglašavanja (19,8\%), ali i lažnih vijesti (11,3\%). Ispitanici su nam pod kategorijom Ostalo odgovorili da je u medijima manje objektivnosti, a više panike, manje je zdravog razuma te kritičnosti prema vlasti, manje je istine, više dizanja panike i senzacionalizma, da je u doba pandemije „isplivalo sve najgore u novinarstvu“, da je manje sporta, „zvijezda“ i influencera.

Tablica 16. Rjeđe objavljivane teme za vrijeme PANCOVID-19 (N=585)

\begin{tabular}{|l|l|}
\hline Političkih tema & $52 \%$ \\
\hline Crne kronike & $32,1 \%$ \\
\hline Senzacionalizma & $29,9 \%$ \\
\hline Manje je istine, više teorija zavjere & $27,5 \%$ \\
\hline Prikrivenog oglašavanja & $19,8 \%$ \\
\hline Lažnih vijesti & $11,3 \%$ \\
\hline Ostalo & $0,2 \%$ \\
\hline
\end{tabular}

Što se baš lažnih vijesti tiče (Tablica 17) ispitanici su ih najčešće prepoznali na internetu, što potvrđuje 65,5\% ispitanika, a prate ih društvene mreže (50,6\%). U znatno manjem opsegu 
lažne vijesti pronađene su na televiziji (23,4\%), dok su tek rijetke lažne vijesti pronađene u tisku (7\%) i na radiju (4,4\%).

Tablica 17. Učestalost lažnih vijesti u pojedinim medijima $(\mathrm{N}=585)$

\begin{tabular}{|l|l|}
\hline Internet & $65,5 \%$ \\
\hline Društvene mreže & $50,6 \%$ \\
\hline Televizija & $23,4 \%$ \\
\hline Tisak & $7 \%$ \\
\hline Radio & $4,4 \%$ \\
\hline Ne znam & $0,3 \%$ \\
\hline Ostalo & $0,2 \%$ \\
\hline
\end{tabular}

Prisutnost teorija zavjera i lažnih vijesti u medijima potvrdilo je $34,2 \%$ ispitanika (Tablica 18) koji nisu znali jesu li čuli provjerenu informaciju ili lažnu vijest kada su se informirali putem medija. No, ovdje je bitno naglasiti da su ispitanici unatoč takvom rezultatu iskazali pozitivan stav prema medijima, jer su naveli da su prateći medije osjećali optimizam i vjerovali da će sve biti u redu, 30,1\% ispitanika, a 21,5\% njih osjećalo se sigurnim i znalo što im je činiti kada se informiraju putem medija. Samo 6,5\% ispitanika smatra da je COVID-19 izmišljena zaraza i ne vjeruju medijima.

Tablica 18. Osjećaji vezani uz informiranje putem medija ( $\mathrm{N}=585)$

\begin{tabular}{|l|l|}
\hline Ne znam jesam li čuo provjerenu informaciju ili lažnu vijest & $34,2 \%$ \\
\hline Osjećam optimizam i vjerujem da će sve biti u redu & $30,1 \%$ \\
\hline Osjećam se sigurnim i znam što mi je činiti & $21,5 \%$ \\
\hline Osjećam određenu dozu straha i nemira i ne znam što mi je činiti & $7,7 \%$ \\
\hline Smatram da je COVID-19 izmišljena zaraza i ne vjerujem medijima & $6,5 \%$ \\
\hline
\end{tabular}

Kada smo ispitanike pitali o tome kojim akterima u komunikaciji u doba pandemije vjeruju, dobili smo nešto drugačiju sliku. Naime, prema Tablici 19, Nacionalni stožer civilne zaštite Republike Hrvatske kao krizni komunikacijski stožer tijelo je kojem su građani najviše vjerovali u razdoblju pandemije koronavirusa. Dok je čak $43,1 \%$ ispitanih vjerovalo Nacionalnom stožeru, povjerenje u Vladu, policiju i vatrogasce je bilo iznimno nisko (od 0,5\% do 1\%). Začudno, ali i mediji su se našli u donjem dijelu tablice kada je riječ o povjerenju ispitanika koji su ih pratili, i to s izrazito niskih $1,4 \%$, a daleko više nego medijima građani vjeruju znanstvenicima, virolozima i epidemiolozima (32\%) i općenito liječnicima, medicinskom 
osoblju i ljekarnicima (13\%). Da je velik broj lažnih vijesti i dezinformacija pridonio činjenici da građani ne vjeruju nikome smatra 3,7\% ispitanika. U kategoriji Ostalo (0,2 \%) dobili smo odgovore ispitanika poput: „više nikome, u početku Stožeru“; „prije sam vjerovao stožeru, sad sve manje bilo kojem akteru“, „sebi“, „Crkvi“, „Bogu“, „, neovisnim portalima“.

Tablica 19. Povjerenje u komunikaciju aktera uključenih u PANCOVID-19 (N=585)

\begin{tabular}{|l|l|}
\hline Nacionalni stožer civilne zaštite Republike Hrvatske & $43,1 \%$ \\
\hline Znanstvenici, virolozi, epidemiolozi & $32 \%$ \\
\hline Liječnici, medicinsko osoblje, ljekarnici & $13 \%$ \\
\hline Nikome & $3,7 \%$ \\
\hline Gospodarstvenici, poduzetnici, kreativni i kulturni djelatnici & $1,5 \%$ \\
\hline Mediji & $1,4 \%$ \\
\hline Vatrogasci & $1 \%$ \\
\hline Vlada RH & $0,5 \%$ \\
\hline Policija & $0,5 \%$ \\
\hline Ostalo & $0,2 \%$ \\
\hline
\end{tabular}

Ispitanici smatraju da su novinarska pitanja postavljena glavnim akterima uključenima $u$ krizu ponekad pridonijela dobivanju informacija i detalja o PANCOVID-19. To smatra 48\% ispitanika, 29,1\% reklo je da je to bio slučaj često, a rijetko 16,6\%.

Tablica 20. Doprinos novinara u dobivanju informacija i detalja o PANCOVID-19 (N=585)

\begin{tabular}{|l|l|}
\hline Nikada & $2,7 \%$ \\
\hline Rijetko & $16,6 \%$ \\
\hline Ponekad & $48 \%$ \\
\hline Često & $29,1 \%$ \\
\hline Uvijek & $3,6 \%$ \\
\hline
\end{tabular}

Da novinari koji su pripremali priloge o COVID-19 rade taj posao neovisno o obrazovanju smatra 51,1\% ispitanika. U većoj mjeri smatraju da su novinari skloni senzacionalizmu $(43,6 \%)$ i manipulaciji $(34,7 \%)$, ali ih također vide kao informatore $(31,5 \%)$ i kritičare postojećeg stanja (26,8\%). Da su novinari visokoobrazovani i školovani za taj posao i da su pismeni smatra tek 15,4\%, odnosno 14,7 \% ispitanika (Tablica 21). Ovi rezultati pokazuju da ima prostora za napredak novinara u profesionalnom usavršavanju, poštivanju etičkih standarda te preuzimanju veće odgovornosti u širenju informacija i izvještavanju javnosti o kriznim situacijama. Činjenica da ispitanici u većoj mjeri smatraju da su novinari skloni senzacionalizmu i manipulaciji u odnosu na to da su novinari visokoobrazovani i školovani 
za taj posao te pismeni govori kako je novinarstvo kao profesija izložena negativnoj percepciji javnosti. Labaš (2010) ističe da Luka Brajnović navodi deset specifičnih dužnosti novinara profesionalca, od kojih su za rezultate našeg istraživanja najvažnije: novinar treba biti odan izabranoj profesiji, kroz školovanje i učenje mora proći određenu pripremu kako bi bio stručno osposobljen za bavljenje novinarskim poslom, usavršavanje novinara nikada nije u potpunosti završeno te se novinar mora pobrinuti za svoje usavršavanje kako bi mogao pružati usluge u korist općeg dobra i u službi društva. Sličnog stava o dužnostima i etičkim aspektima su Claude-Jean Bertrand i Guido Gatti, a ističu da su danas novinari sve obrazovaniji, žele izvršavati dužnosti kako treba te samim time postići veći društveni ugled, no ispaštaju zbog pogrešaka manjine. Labaš dalje navodi (2010) da u medijima vlada pojedinačna neetičnost, odnosno „nemoralnost nekoliko traumatiziranih, umišljenih ili amorfnih profesionalaca baca sjenu na novinarstvo u cjelini, naročito kada je riječ o reprezentativnom ili monopoliziranom mediju“ (prema Gatti, 1992, str. 125). Zbog ovakvih izazova u novinarstvu kao profesiji, možda je danas više nego prije, potrebno preispitati i vrednovati profesionalni rad te se upitati koliko etički i profesionalno novinar odgovara na određene standarde kojih se dužan držati.

Tablica 21. Mišljenje o novinarima koji su pripremali priloge o COVID-19 (N=585)

\begin{tabular}{|l|l|}
\hline Rade taj posao neovisno o obrazovanju & $51,1 \%$ \\
\hline Skloni senzacionalizmu & $43,6 \%$ \\
\hline Skloni manipulaciji & $34,7 \%$ \\
\hline Informatori & $31,5 \%$ \\
\hline Površni & $29,9 \%$ \\
\hline Kritičari postojećeg stanja & $26,8 \%$ \\
\hline Glasnogovornici građana & $17,3 \%$ \\
\hline Visokoobrazovani i školovani za taj posao & $15,4 \%$ \\
\hline Pismeni su & $14,7 \%$ \\
\hline Ostalo & $0,2 \%$ \\
\hline
\end{tabular}

Međutim, valja priznati da nije bilo lagano obavljati novinarski posao za vrijeme PANCOVID-19, što smatra 40,7\% ispitanika (Tablica 22). Novinari su tijekom PANCOVID-19 radili u vrlo stresnim uvjetima, odlazili u zaražena područja kako bi informirali javnost o novim informacijama o bolesti, sudjelovali su na konferencijama Nacionalnog stožera i brzo prenosili informacije, poticali prikladna ponašanja i način djelovanja tijekom krize te su i promotivnim tekstovima i spotovima smanjili nervozu, strah i paniku. Takav pristup 
pokazuje da je prema načelima profesije, a Labaš (2010) zaključuje da novinar dužan istraživati društvene i javne odnose, biti prepoznat kao sigurni poznavatelj problema i tema koja obrađuje, a ujedno i sposoban izvještavati zanimljivo, istinito, uvjerljivo i kompetentno.

Tablica 22. Ocjena novinarskog posla za vrijeme PANCOVID-19 (N=585)

\begin{tabular}{|l|l|}
\hline Uopće se ne slažem & $22,9 \%$ \\
\hline Ne slažem se & $40,7 \%$ \\
\hline Niti se ne slažem niti se slažem & $30,3 \%$ \\
\hline Slažem se & $4,6 \%$ \\
\hline U potpunosti se slažem & $1,5 \%$ \\
\hline
\end{tabular}

Konačno, kada smo ispitanike pitali koju bi zaključnu ocjenu dali medijima i njihovom doprinosu razumijevanju krize uzrokovane koronavirusom, ocjenu dobar 3 dalo im je 41,7\% ispitanika, a njih 36,9\% dalo bi ocjenu vrlo dobar 4 (Tablica 23). Ovakvi rezultati potvrđuju i međunarodna istraživanja prema kojima su mediji uspjeli pridonijeti razumijevanju krize i objasniti ljudima što im je činiti.

Tablica 23. Ocjena doprinosa medija razumijevanja PANCOVID-19 (N=585)

\begin{tabular}{|l|l|}
\hline 3 & $41,7 \%$ \\
\hline 4 & $36,9 \%$ \\
\hline 5 & $10,1 \%$ \\
\hline 2 & $6,7 \%$ \\
\hline 1 & $4,6 \%$ \\
\hline
\end{tabular}

\section{Smjernice za snažnije medijsko djelovanje u krizama}

Mediji su u svakoj krizi, a osobito u ovoj aktualnoj pandemiji koronavirusa, važan izvor informacija. Dok se sami novinari i urednici susreću s novostima i nepoznanicama, publika očekuje jasne i kratke informacije koje će im pomoći u svakodnevnom funkcioniranju. Mediji su pokazali odgovornost prema sadržaju koji stvaraju, no rezultati pokazuju da ima dosta prostora za napredak. 
1. Mediji neprestano moraju graditi svoj odnos s publikom i nastojati održati povjerenje u sadržaj koji objavljuju. Tome snažno pridonosi odabir relevantnih izvora kojima publika vjeruje.

2. Novinari u pojedinim medijima trebaju izbjegavati širenje panike, straha i lažnih vijesti kao i sudjelovanje u općoj infodemiji koja narušava odnos i povjerenje između publike i medija.

3. Novinari trebaju biti prijatelj javnosti, koja će svakodnevno pratiti medije znajući da se tamo mogu informirati o događajima, s naglaskom na poznavanje točnih i provjerenih informacija o tijeku događaja. Medijski sadržaj i medijska istina trebali bi biti jasno odvojeni od lažnih vijesti, manipulacija i dezinformacija, iskrivljene stvarnosti, mišljenja ili različitih komentara nepouzdanih izvora.

4. Novinari neprestano trebaju ulagati u svoje obrazovanje i poznavati problematiku koju obrađuju u mediju u kojem rade. Uz obrazovanje i edukacije, pridržavanje standarda novinarske struke i etičkih kodeksa od neizmjerne je važnosti za svakoga novinara, a samim time i za njegovu medijsku kuću.

5. Novinari i urednici trebaju poštivati određene dužnosti koje se od njih očekuju u obavljanju posla, poput poznavanja problema u društvu i javnosti, postavljanju kritičkih pitanja na koja publika želi čuti odgovor, kvalitetne obrade određene teme uz zanimljivo, istinito, uvjerljivo i kompetentno izvještavanje.

6. Samo takvim načinom rada, novinari i urednici moći će se uspješnije boriti protiv senzacionalizma, manipulacije, teorija zavjera i lažnih vijesti, a na kraju krajeva i protiv negativne percepcije javnosti o novinarima/medijima.

7. Novinari moraju biti zaštićeni tijekom svog rada na terenu i izvještavanju u krizi, državna tijela trebaju razvijati sustav podrške novinarima i urednicima kako bi uz potrebne tehničke i financijske mogućnosti mogli adekvatno obavljati svoj posao i imati pristup svim informacijama koje su potrebne za kvalitetno medijsko izvještavanje u krizi. 


\section{Zaključak}

U ovome je radu prikazana uloga medija, posebno digitalnih medija u suvremenom društvu i analizirane su navike njihovog korištenja, vjerodostojnost njihova sadržaja u očima publike i mišljenja o lažnim vijestima za vrijeme kriznoga razdoblja u današnjim društvima, a koje je poznato i kao „doba pandemije koronavirusa“, dok je Svjetska zdravstvena organizacija upozorila i na činjenicu da je istodobno riječ bila i o infodemiji. Upravo je tim terminom potvrđena važnost uloge medija, koji su mogli pridonijeti smirivanju krize ili su mogli prenositi dezinformacije, lažne vijesti i vijesti vezane uz teoriju zavjere i to upravo u doba kada su publici bili najpotrebniji. Naime, u ovo pandemijsko doba došlo je do zatvaranja odgojno-obrazovnih ustanova, prekida javnog autobusnog, tramvajskog i željezničkog prometa, zatvaranja uslužnih djelatnosti i prestanka poljoprivredne, poduzetničke i gospodarske aktivnosti, te su ljudi bili prisiljeni izbjegavati društvene fizičke kontakte, pri čemu su im najvažniji izvori informacija bili upravo mediji kao takvi. Ova vrsta krizne situacije stvorila je stres, a nije zaobišla niti medije na koje su se ljudi oslanjali više nego inače. Pri tome su se, kao što je već prethodno rečeno, mediji mogli potvrditi kao snažni izvori informiranja, odgoja i obrazovanja te zabave ili kao prenositelji uznemirujućih i lažnih vijesti u svakodnevici ljudi. Istraživanje predstavljeno i raspravljeno u ovome radu za cilj je imao ispitati ulogu medija kao važnog izvora informacija u doba pandemije koronavirusa (PANCOVID-19), a provedeno je metodom ankete. Prikupljeni rezultati istraživanja u kojem je sudjelovalo 585 ispitanika u dobi od 18 do 65 godina pokazali su da su mediji publici važni u svakodnevnom životu, te da su medije za vrijeme pandemije koronavirusa najviše koristili za informiranje, što je ukazalo na značajniji porast korištenja medija u odnosu na razdoblje prije pandemije. Internet je na prvome mjestu po korištenju za vrijeme PANCOVID-19, a ispitanici su ga najviše koristili u informativne svrhe - njih čak 88,5\% (Tablica 6). Slijedi televizija koju je pratilo isto tako visokih $80,9 \%$ ispitanika. Nešto manje su se koristile društvene mreže (52\%), a daleko manje se za informiranje koristio radio (26,2\%). Internet je gotovo kod više od polovice ispitanika medij koji za informiranje kombiniraju s nekim drugim medijem. Jednako tako, ispitanici su potvrdili da ih je najviše zanimalo stanje i broj zaraženih, ali i protuepidemijske mjere, način sprječavanja širenja bolesti, život tijekom bolesti, kao i gospodarska kriza. Istodobno su u tom razdoblju primijetili da je u medijima manje političkih tema, crne kronike i senzacionalizma, ali su također naveli 
da su primijetili da je manje istine, a više teorija zavjere. Ispitanici su primijetili i manje prikrivenog oglašavanja, ali i lažnih vijesti koje su najčešće prepoznavali na internetu i na društvenim mrežama. U znatno manjem opsegu lažne vijesti ispitanici su pronalazili na televiziji, a vrlo rijetko u tisku i na radiju, pa slobodno možemo zaključiti da su mediji i prije i tijekom krize zbog pandemije koronavirusa ostali važan izvor informacija u koje korisnici imaju povjerenja, a trendovi i navike medijskih publika potvrdile su da su mediji značajni izvor informacija u svakodnevici. Rezultati istraživanja su pokazali da su mediji važan izvor informacija u koje ispitanici imaju povjerenja, a informacije su im pomogle u samom razumijevanju krize i usmjeravanju prema odgovarajućem ponašanju u kriznoj situaciji. Međutim, ispitanici su istaknuli da više vjeruju znanstvenicima, liječnicima, epidemiolozima i virolozima, a manje novinarima, što upućuje na činjenicu da je odnos između medija i publike i dalje ambivalentan, to jest da publika s jedne strane cijeni i ističe važnu ulogu medija, ali još uvijek kritički promatra svakodnevno novinarsko djelovanje, te su medijima dali dobru ocjenu ističući njihov doprinos razumijevanju krize uzrokovane koronavirusom, pa će u drugim radovima i istraživanjima ove teme svakako biti zanimljivo uspoređivati rezultate i mišljenje publike o medijskome djelovanju u krizi. 


\section{Literatura}

- Dumičić, K., Žmuk, B. (2009). Karakteristike korisnika interneta u Hrvatskoj i reprezentativnost internetskih anketa. Zbornik Ekonomskog fakulteta u Zagrebu, 7 (2), 116-124.

- Dw.com (2020). Dezinformacije i propaganda u doba korone. Dostupno na: https://www.dw.com/bs/dezinformacije-ipropaganda-u-doba-korone/a-52970475, pristupljeno 31. svibnja 2020.

- Edukacije.hr (2020). Kako prepoznati lažne vijesti? Dostupno na: https://www.edukacije.hr/2020/04/kako-prepoznatilazne-vijesti/,pristupljeno 1. lipnja 2020.

- Enders, S. (2020). Von wegen passives Publikum! Über die Macht und Verantwortung vone Mediennutzer_innen. Communicatio Socialis, 53 (2), 133-135.

- Funiok, R. (2020). Verantwortliche Mediennutzung. Wünschenswerte Selbstverpflichtungen von Rezipient_innen und Nutzer_innen. Communicatio Socialis, 53 (2), 136-147.

- Hec.edu (2020). What is the Role of Social Media During the COVID-19 Crisis? Dostupno na: https://www.hec.edu/en/knowledge/ instants/what-role-social-media-during-covid-19-crisis-0, pristupljeno 1. lipnja 2020.

- Ivanišin, M. (2011). (Media) Reality: Where is the Crisis. U: Labaš, D. (ur.), Komunikacija i mediji u krizi (str. 29-40). Zagreb: Hrvatski studiji.

- Jugo, D. (2017). Menadžment kriznog komuniciranja. Zagreb: Školska knjiga, Edward Bernays Visoka škola za komunikacijski menadžment.

- Kanajet, K., Jakopović, H. (2019). Izvještavanje o krizi i krizno komuniciranje Agrokora u 2017. godini putem internetskih platformi Večernji.hr i Agrokor.hr. Medijska istraživanja, 25 (1), 55-81.

- Koronavirus.hr (2020). Dosttupno na: https://www.koronavirus.hr/, pristupljeno 28. svibnja 2020.

- Kučiš, V., Đuho, N., Balabanić, I. (2019). Zastupljenost i obilježja društveno neprihvatljivog govora o političkim strankama na internetskim portalima na primjeru prosvjeda u Vukovaru 2018. godine. Medijska istraživanja, 25 (2), 69-87.

- Labaš, D. (2010). Luka Brajnović - od vjernosti sebi do vjerodostojnosti profesije. Medijske studije, 1 (1-2), $171-182$.

- Labaš, D. (2011). Komunikacija i mediji u krizi. Zagreb: Hrvatski studiji.

- Novak, B. (2001). Krizno komuniciranje i upravljanje opasnostima. Zagreb: Binoza press.

- Plenković, M. (2015). Krizno komuniciranje. Media, culture and public relations, 6 (2), 113-118.

- Propaganda.mediaeducationlab.com (2020). Propaganda je svugdje oko nas. Dostupno na: https://propaganda.mediaeducationlab. com/hr/node/1, pristupljeno 20. svibnja 2020.

- Reutersinstitute.politics.ox.ac.uk (2020). Navigating the 'infodemic': how people in six countries access and rate news and information about coronavirus. Dostupno na: https://reutersinstitute.politics.ox.ac.uk/infodemic-how-people-six-countriesaccess-and-rate-news-and-information-about-coronavirus, pristupljeno 1. lipnja 2020.

- Showcase.24sata (2020). Medijske navike u Republici Hrvatskoj. Dostupno na: https://showcase.24sata.hr/2019 hosted creatives/ medijske-navike-hr-2019.pdf, pristupljeno 28. svibnja 2020.

- Tkalac Verčič, A. (2015). Odnosi s javnošću. Zagreb: Hrvatska udruga za odnose s javnošću.

- Tomić, Z. i Milas, Z. (2007). Strategija kao odgovor na krizu. Politička misao, 44 (1), 137-149.

- Wied, K., Pies, J., Büsching, T. (2020). 'Social-clever-komepetent' kommunizieren. Empfehlungen für eine effiziente Kommunikation in der digitalen Welt. Communicatio Socialis, 53 (2), 172-182.

- Zeilinger, T. (2020). Das Netz der öffentlichen Kommunikation. Publikum und Medien in interaktiven Zeiten. Communicatio Socialis, 53 (2), 158-171. 


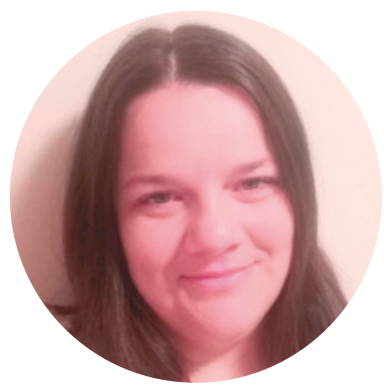

\section{Petra Begović}

Petra Begović zaposlena je na Televiziji Zapad kao novinarka i urednica. Za svoj rad nagrađena je nagradom "Svjetionik“ Hrvatske mreže protiv siromaštva te Godišnjom nagradom za novinarske radove koji promiču zaštitu na radu. Stručna je suradnica $u$ znanosti i visokom obrazovanju na Fakultetu hrvatskih studija na kolegijima Televizijsko novinarstvo i Metode istraživanja masovne komunikacije. Članica je Društva za komunikacijsku i medijsku kulturu. Diplomirala je povijest i komunikologiju na Hrvatskim studijima Sveučilišta u Zagrebu. Polaznica je IV. Komunikološke škole Matice hrvatske i dobitnica Rektorove nagrade. Trenutno je uključena u projekt „mimladi.hr - novo lice naslovnice" koji podupire Ministarstvo kulture i medija, a sufinancira Europski socijalni fond u sklopu Operativnog programa Učinkoviti ljudski potencijali 2014. - 2020.

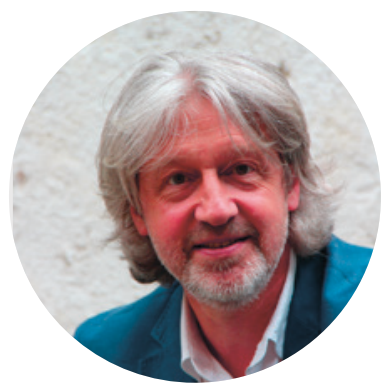

Prof. dr. sc. Danijel Labaš

Prof. dr. sc. Danijel Labaš redoviti je profesor na Odsjeku za komunikologiju Hrvatskih studija Sveučilišta u Zagrebu. Autor i urednik više knjiga i zbornika, kao i znanstvenih i stručnih članaka, posebno s područja medijske pismenosti i etike. Član je Hrvatskog povjerenstva za suradnju s Organizacijom ujedinjenih naroda za prosvjetu, znanost i kulturu (UNESCO), Matice hrvatske i Hrvatskog društva katoličkih novinara. Od 1998. predsjedava žirijem Glasa Koncila koji na Danima hrvatskog filma dodjeljuje filmsku nagradu za promicanje etičkih vrijednosti na filmu Zlatna uljanica, te autor i voditelj emisije Okrugli stol Trećega programa Hrvatskog radija. Predsjednik je Društva za komunikacijsku i medijsku kulturu i voditelj krovnog projekta Djeca medija, te je jedan od organizatora i suvoditelj Komunikološke škole Matice hrvatske. 